\title{
EDITORIAL
}

\section{Concurso para provimento de cargos de Professor Assistente}

O assunto do dia, nesta Escola, como aliás em toda a Universidade de São Paulo, é o concurso para provimento de cargos de Professor Assistente.

A Constituição do Brasil determina que depende de habilitaçao em concurso de t/tulos e provas o provimento dos cargos iniciais das carreiras do magistério superior do ensino oficial, cargos estes que, segundo a Lei nP 5.539/68, são os de Professor Assistente.

De acordo com a mesma Lei, para iniciação das atividades de ensino, poderão ser contratados auxiliares de ensino, por dois anos, renováveis por mais dois.

Baseado no texto da Constituição e no espirito da Lei no 5.539, o novo Estatuto da Universidade de São Paulo, baixado após a reforma universitária e vigente a partir de 1970, estipulou a exigência de habilitação em concurso de t/tulos e provas para o provimento dos cargos de Professor Assistente e prazo de três anos para os contratos de auxiliar de ensino, renováveis por mais três.

Os antigos cargos de Instrutor foram redistribuidos pelas Unidades de ensino da USP, cabendo a esta Escola 14 cargos (Resolução no 299/73).

Não foram eles, entretanto, postos, desde logo, em concurso, em virtude, principalmente, de duas grandes dificuldades enfrentadas pelas IJni dades de ensino: falta de verbas e falta de regulamentaçäo dos concursos.

Em 1974 todas as Unidades tiveram em seu orçamento verba para o provimento de dois cargos mas, ainda assim, com pouquissimas exceçôes, os concursos não se realizaram; faltava ainda a sua regulamentação. Esta 
s6 veio com a Resolucão n! 630, baixada em abril de 1975, complementada pela Resoluç̃o nQ 722, de julho do mesmo ano.

O orçamento de 1975 nf́o previu verba espocial para cargos de Professor Assistente, em vista do que a Resolugão no 630/75 considerou recursos disponiveis, para a realização dos concursos, aqueles comprometidos com as funçбes exercidas por contrato. Em outras palauras, se um candidato de fora obtiver melhor classificação que o ocupante da funç̃o correspondente ao cargo para o qual foi realizado o concurso, este terá seu contrato automaticamente rescindido.

A possibilidade de perder bons elementos, ja ajustados ao ensino de determinadas disciplinas, preocupou as chefias de Departamento tanto quanto os auxiliares de ensino.

Uma terceira dificuldade de monta era a qualificação que seria exigida dos candidatos. 0 artigo 90 do Estatuto reza que é exigida comprovação de atividade universitária prévia equivalente, no mínimo, à de pós-graduação em nivel de mestrado.

Ora, anteriormente à vigência do novo Estatuto, pouqu/ssimos cursos de pós-graduação havia na USP em nível de Mestrado, nos moldes determinados peto Conse/ho Federal de Educação (Parecer no 77/69).

Os antigos cursos de pos-graduação, inclusive os desta Escola, haviam sido suspensos, a fim de se adptarem łs novas normas.

Tão lago as candiçães o permitiram, as Unidades de ensino, uma a uma, foram reabrindo seus cursos de pos-graduaç̃o, já agora obedecendo às normas baixadas pelo Conselho Federal de Educacáo e pela propria Universidade de São Paulo.

Como um Mestre não se faz da noite para o dia, em razão das exigências para a obtenç5o do grau, não serd possivel que as centenas de antigos instrutores da USP, há muitos anos contratados e agora classificados como auxiliares de ensino, se qualifiquem para o concurso em curto prazo.

Felizmente o novo Estatuto permite que os antigos cursos de pos-graduaça sejam validos para o fim de habilitação a concurso de ingresso na carreira docente (artigo 149), validade essa que, de acordo com a Resolução 
n? 722/75, deve ser julgada pelo Conselho de Ensino, Pesquisa e Extensão de Serviços à Comunidade da USP (CEPE)

Esta, pois, resolvido o caso dos que ja obtiveram o grau de Mestre e dos que fizeram o antigo curso de pos-graduaçao julgado valido pelo CEPE; resta, porém, o daqueles que acham serem suas atividades universitárias equivalentes à de pos-graduação em nivel de mestrado. Exemplo: os alunos de pós-graduação que pretendem obter diretamente o grau de Doutor e que ja integralizaram os 120 créditos exigidos para o grau de Mestre.

O CEPE, ao estudar a matéria, decidiu que atividade "equivalente no minimo, à de pós-graduação, em nivel de mestrado" é o proprio grau de Mestre, com o que não se conformam os interessados; prometem voltar a carga a fim de obterem o consentimento do CEPE para se inscreverem ao concurso.

Todos estes problemas retardaram a realização do concurso até o momento em que foi baixada uma resolução so permitindo a contratação de novos auxiliares de ensino, após 31 de outubro de 1975, às Unidades que tenham iniciado essa atividade.

As Unidades de ensino não podem, pois, protelar mais tais concursos; com verba ou sem verba, eles terão que ser realizados. Unidades ha que só abriram concurso para um cargo.

Esta Escola o fez para os 14 cargos de que dispunha, apesar da intensidade de trabalho para os Departamentos e para a Secretaria, no periodo de 15 de março a 14 de abril, pois, o concurso deve ser efetuado no prazo compreendido entre trinta e sessenta dias a contar do encerramento das inscriçes. Inscreveram-se vinte e duas auxiliares de ensino e um elemento de fora.

A Escola de Enfermagem da USP, que jamais conseguira ter seu quadro de docentes, a que so contava com professoras e auxiliares de ensino contratadas e umas poucas estaveis por força do artigo 177 da Constituição, pas sard́ agora a ter professoras efetivas, como as demais Unidades de ensino da Universidade.

Foi preciso que chegasse a idade de Cristo para obter o que vinha tentando ha 33 anos, confirmando, assim, o ditado popular: "Deus tarda mas กล̃o fa/ta" (MRSP). 